\title{
Estimating components of forest evapotranspiration: A footprint approach for scaling sap flux measurements
}

\section{Authors: A. Christopher Oishi, Ram Oren, and Paul C. Stoy}

NOTICE: this is the author's version of a work that was accepted for publication in Agricultural and Forest Meteorology. Changes resulting from the publishing process, such as peer review, editing, corrections, structural formatting, and other quality control mechanisms may not be reflected in this document. Changes may have been made to this work since it was submitted for publication. A definitive version was subsequently published in Agricultural and Forest Meteorology, VOL\# 148, ISSUE\# 11, (October 2018), DOI\# 10.1016/j.agrformet.2008.06.013.

Oishi, A. Christopher, Ram Oren, and Paul C. Stoy. "Estimating Components of Forest Evapotranspiration: A Footprint Approach for Scaling Sap Flux Measurements." Agricultural and Forest Meteorology 148, no. 11 (October 2008): 1719-1732. doi:10.1016/j.agrformet.2008.06.013.

Made available through Montana State University's ScholarWorks

scholarworks.montana.edu 


\title{
Estimating components of forest evapotranspiration: A footprint approach for scaling sap flux measurements
}

\author{
A. Christopher Oishi ${ }^{a, *}$, Ram Oren $^{a}$, Paul C. Stoy ${ }^{a, b}$ \\ a Nicholas School of the Environment and Earth Sciences, Duke University, Box 90328, Durham, NC 27701, USA \\ ${ }^{\mathrm{b}}$ School of GeoSciences, Department of Atmospheric and Environmental Science, University of Edinburgh, Edinburgh EH9 3JN, UK
}

\begin{abstract}
A B S T R A C T
Forest evapotranspiration (ET) estimates that include scaled sap flux measurements often underestimate eddy covariance (EC)-measured latent heat flux (LE). We investigated potential causes for this bias using 4 years of coupled sap flux and LE measurements from a mature oak-hickory forest in North Carolina, USA. We focused on accuracy in sap flux estimates from heat dissipation probes by investigating nocturnal water uptake, radial pattern in flux rates, and sensor-to-stand scaling. We also produced empirical functions describing canopy interception losses (measured as the difference between precipitation and throughfall) and soil evaporation (based on wintertime eddy covariance fluxes minus wintertime water losses through bark), and added these components to the scaled sap flux to estimate stand evapotranspiration $\left(\mathrm{ET}_{\mathrm{S}}\right)$. We show that scaling based on areas in which the leaf area index of predominant species deviates from that of the EC footprint can lead to either higher or lower estimate of $\mathrm{ET}_{\mathrm{S}}$ than $\mathrm{LE}$ (i.e. there is no bias). We found that accounting for nocturnal water uptake increased the estimate of growing season transpiration by an average of $22 \%$, with inter-annual standard deviation of $4 \%$. Annual $\mathrm{ET}_{\mathrm{S}}$ estimate that included sap flux corrected for nocturnal flux and scaled to the EC footprint were similar to LE estimates (633 \pm 26 versus $604 \pm 19 \mathrm{~mm}$, respectively). At monthly or shorter time scales, $\mathrm{ET}_{\mathrm{S}}$ was higher than LE at periods of low flux, similar at periods of moderate flux, and lower at periods of high flux, indicating potential shortcomings of both methods. Nevertheless, this study demonstrates that accounting for the effects of nocturnal flux on the baseline signal was essential for eliminating much of the bias between EC-based and componentbased estimates of ET, but the agreement between these estimates is greatly affected by the scaling procedure.
\end{abstract}

\section{Introduction}

Stand-level water vapor fluxes are now monitored across many ecosystems with eddy covariance systems, providing continuous, long-term measurements of latent heat flux (LE); however, this approach does not quantify the individual components of evapotranspiration: interception of precipitation during rain events $\left(I_{C}\right)$, evaporation from the soil and forest floor $\left(E_{S}\right)$, and transpiration $\left(E_{C}\right)$. (See Table 1 for a full list of abbreviations.) Quantifying these components is an essential step in assessing and modeling the processes controlling these physiological and ecosystem fluxes. A common approach for estimating $E_{C}$ is the scaling of sap flux density $\left(J_{S}\right)$ measured with the popular thermal dissipation probes (Granier, 1987; Oren et al., 1998b). Correct applications of these probes can provide reliable estimates of species-specific transpiration at 


\begin{tabular}{|c|c|c|}
\hline Abbreviation & Definition & Units \\
\hline$A_{B}$ & Basal area of trees per unit ground area & $\mathrm{cm}^{2} \mathrm{~m}^{-2}$ \\
\hline$A_{\mathrm{Fj}}$ & Integrated area beneath fitted curve of radial sap flux profile (see Eq. (4)) & $\mathrm{cm}^{2}$ \\
\hline$A_{S}$ & Sapwood area of trees per unit ground area & $\mathrm{cm}^{2} \mathrm{~m}^{-2}$ \\
\hline$A_{\mathrm{Si}}$ & $A_{S}$ for species $i$ & $\mathrm{~cm}^{2} \mathrm{~m}^{-2}$ \\
\hline$A_{\text {sih }}$ & $\mathrm{A}_{\mathrm{Si}}$ for one-hectare plot & $\mathrm{cm}^{2} \mathrm{~m}^{-2}$ \\
\hline$A_{S j}$ & Sapwood area for individual tree & $\mathrm{cm}^{2} \mathrm{~m}^{-2}$ \\
\hline$c_{j}$ & $\begin{array}{l}\text { Distance from center of tree to centroid of fitted curve of radial sap flux } \\
\text { profile (see Eq. (4)) }\end{array}$ & $\mathrm{cm}$ \\
\hline D & Vapor pressure deficit & $\mathrm{kPa}$ \\
\hline$D_{\mathrm{Z}}$ & Day-length-normalized vapor pressure deficit & $\mathrm{kPa}$ \\
\hline DBH & Tree diameter at breast height & $\mathrm{cm}$ \\
\hline$E_{C}$ & Canopy transpiration & mm time ${ }^{-1}$ \\
\hline$E_{\mathrm{Ci}}$ & $E_{C}$ for species i & mm time ${ }^{-1}$ \\
\hline$E_{\text {Cih }}$ & $E_{\mathrm{Ci}}$ for one-hectare plot & $\mathrm{mm}$ time $^{-1}$ \\
\hline$E_{\mathrm{S}}$ & Soil surface evaporation & $\mathrm{mm}$ time $^{-1}$ \\
\hline ET & Evapotranspiration & mm time ${ }^{-1}$ \\
\hline $\mathrm{ET}_{\mathrm{S}}$ & Evapotranspiration, estimated from sap flux-scaled budget & $\mathrm{mm}$ time $^{-1}$ \\
\hline$I_{C}$ & Canopy interception & mm time ${ }^{-1}$ \\
\hline$J_{\mathrm{S}}$ & Sap flux density & $\mathrm{g} \mathrm{H}_{2} \mathrm{O} \mathrm{m} \mathrm{m}^{-2} \mathrm{~s}^{-1}$ \\
\hline$J_{\mathrm{Si}}$ & Sap flux density for species i & $\mathrm{g} \mathrm{H}_{2} \mathrm{O} \mathrm{m} \mathrm{m}^{-2} \mathrm{~s}^{-1}$ \\
\hline LAI & Leaf area index & $\mathrm{m}^{2} \mathrm{~m}^{-2}$ \\
\hline LE & Latent heat flux ${ }^{\mathrm{a}}$ & mm time t $^{-1}$ \\
\hline$P$ & Precipitation & mm time t $^{-1}$ \\
\hline$P_{\mathrm{T}}$ & Throughfall $\left(P-I_{C}\right)$ & mm time ${ }^{-1}$ \\
\hline PAR & Photosynthetically active radiation & $\mu \mathrm{mol} \mathrm{m} \mathrm{m}^{-2} \mathrm{~s}^{-1}$ \\
\hline $\mathrm{RH}$ & Relative humidity & $\%$ \\
\hline SLA & Specific leaf area & $\mathrm{cm}^{2} \mathrm{~g}^{-1}$ \\
\hline $\mathrm{T}_{\mathrm{A}}$ & Air temperature & ${ }^{\circ} \mathrm{C}$ \\
\hline $\mathrm{T}_{\mathrm{B}}$ & Bark thickness & $\mathrm{mm}$ \\
\hline $\mathrm{T}_{\mathrm{SW}}$ & Sapwood thickness & $\mathrm{cm}$ \\
\hline $\mathrm{V}_{\mathrm{j}}$ & Volume of a rotated geometric solid (see Eq. (4)) & $\mathrm{cm}^{3}$ \\
\hline$\Delta \mathrm{T}$ & Temperature difference between heated and unheated sap flux probes & $\mathrm{mV}$ \\
\hline$\Delta \mathrm{T}_{\max }$ & Maximum daily $\Delta T$ & $\mathrm{mV}$ \\
\hline$\theta$ & Volumetric soil moisture content & $\mathrm{m}^{3} \mathrm{~m}^{-3}$ \\
\hline
\end{tabular}

${ }^{a}$ LE is commonly expressed in terms of $\mathrm{W} \mathrm{m}^{-2}$ but can be converted to units of $\mathrm{mm}$ by considering the latent heat of vaporization and the density of air for studies of the water balance.

the stand level (Clearwater et al., 1998; Ford et al., 2007; Lu et al., 2004; Oren et al., 1998b; Phillips et al., 1996; Williams et al., 2004).

Although some studies have found good agreement between component-based estimates of evapotranspiration $\left(\mathrm{ET}_{\mathrm{S}}\right.$ ), including sap flux-based $\mathrm{E}_{\mathrm{C}}$, and LE (Arneth et al., 1996; Granier, 1987; Granier et al., 2000; Köstner et al., 1992), others have found that thermal dissipation probes may underestimate high flux rates, generally leading to $\mathrm{ET}_{\mathrm{S}}$ that is lower than LE (Bovard et al., 2005; Hogg et al., 1997; Schäfer et al., 2002; Wilson et al., 2001). This discrepancy may be the result of three methodological challenges: (1) improper processing of the sap flux sensor output, including failure to account for non-zero nocturnal water uptake, (2) failing to scale sap flux measurements to a similar footprint as the LE measurements, and (3) failing to accurately quantify all components of evapotranspiration when comparing $\mathrm{ET}_{\mathrm{S}}$ to LE.

Some recent research has focused on (1), demonstrating that accurate stand-level hydrologic budgets must account for nocturnal sap flux, used either to recharge storage (Daley and Phillips, 2006; Köstner et al., 1992; Meinzer et al., 2001; Phillips et al., 1996) or to provide for water loss from leaves maintaining finite stomatal conductance at night (Daley and Phillips, 2006; Dawson et al., 2007; Oren et al., 1999). There is some evidence that nocturnal sap flow observed in data from heat pulse velocity sensors may have been missed in data from thermal dissipation sensors (Hogg et al., 1997), possibly because of incorrect signal processing (Lu et al., 2004). In order to process data from thermal dissipation sensors, Lu et al. (2004) pointed out that the baseline connecting points where zero flux occurs $\left(\Delta T_{\max }\right.$, see Eq. (3) in Section 2$)$ must be dynamic, reflecting changes in sapwood moisture content, and might not be reached every night. Mischaracterizing this baseline not only results in missed nocturnal water uptake, but translates to a large underestimate of daytime transpiration.

The second methodological challenge, scaling to the appropriate footprint, requires that probes are installed properly in sapwood (Clearwater et al., 1998), whole-tree transpiration estimates account for radial variability in flow for a sufficient number of sample trees (Ford et al., 2004; Phillips et al., 1996), and species-specific sapwood area within the reference footprint is characterized accurately (Wullschleger et al., 2001). Finally, because other evaporative fluxes may contribute to nearly half of evapotranspiration (Table 2), any comparison of $\mathrm{ET}_{\mathrm{S}}$ and LE requires reliable estimates of $E_{S}$ and $I_{C}$, yet $E_{S}$ is not often measured directly and is difficult to model (Wilson et al., 2000).

Here, we investigate the relative contributions of the first two methodological challenges to the discrepancy between 
Table 2 - Components of forest evapotranspiration from published studies using thermal dissipation probes in comparable regional deciduous forests and from this study

\begin{tabular}{|c|c|c|c|c|c|c|c|c|c|c|}
\hline Site description & Year & $P$ & $I_{C}$ & $E_{S}$ & $E_{C}$ & $\mathrm{ET}_{\mathrm{S}}$ & ET & LOC & $E_{C} / E T$ & Reference \\
\hline \multicolumn{11}{|l|}{ Annual sums } \\
\hline \multirow{4}{*}{$\begin{array}{l}\text { Eddy covariance-generated } \\
\text { estimates, same study area }\end{array}$} & 2002 & 1092 & & & 440 & & 610 & & 0.72 & \multirow[t]{4}{*}{ Stoy et al. (2006) } \\
\hline & 2003 & 1346 & & & 410 & & 580 & & 0.71 & \\
\hline & 2004 & 992 & & & 460 & & 640 & & 0.72 & \\
\hline & 2005 & 934 & & & $460^{\mathrm{a}}$ & & 640 & & 0.72 & \\
\hline \multirow{2}{*}{$\begin{array}{l}\text { Upland oak-dominated } \\
\text { broadleaf forest, } \\
\text { Oak Ridge, TN }\end{array}$} & 1998 & 1225 & 104 & 86 & 230 & 420 & $547,502^{b}$ & $-127,-82$ & $0.42,0.46$ & \multirow[t]{2}{*}{ Wilson et al. (2001) } \\
\hline & 1999 & 1152 & 105 & 91 & 269 & 465 & $605,642^{b}$ & $-140,-177$ & $0.44,0.42$ & \\
\hline \multirow{4}{*}{$\begin{array}{l}\text { Upland oak-dominated } \\
\text { broadleaf forest, } \\
\text { Oak Ridge, TN }\end{array}$} & 2000 & 766 & & & 325 & & & & & \multirow{4}{*}{$\begin{array}{l}\text { Wullschleger } \\
\text { and Hanson (2006) }\end{array}$} \\
\hline & 2001 & 539 & & & 309 & & & & & \\
\hline & 2002 & 730 & & & 255 & & & & & \\
\hline & 2003 & 968 & & & 315 & & & & & \\
\hline \multirow[t]{4}{*}{ This study } & 2002 & 1092 & 189 & 84 & 336 & 610 & 577 & 33 & 0.58 & \multirow[t]{4}{*}{ This study } \\
\hline & 2003 & 1346 & 236 & 102 & 329 & 668 & 618 & 50 & 0.53 & \\
\hline & 2004 & 992 & 181 & 108 & 346 & 635 & 618 & 18 & 0.56 & \\
\hline & 2005 & 934 & 157 & 119 & 343 & 619 & 605 & 15 & 0.57 & \\
\hline \multicolumn{11}{|l|}{ Growing season } \\
\hline $\begin{array}{l}\text { Different plots within } \\
\text { same study area }\end{array}$ & 1997 & 626 & 88 & & 264 & & & & & $\begin{array}{l}\text { Pataki and } \\
\text { Oren (2003) }\end{array}$ \\
\hline $\begin{array}{l}\text { Upland hardwood stand, } \\
\text { Duke Forest, NC }\end{array}$ & 1993 & 642 & 90 & & 278 & & & & & $\begin{array}{l}\text { Pataki and } \\
\text { Oren (2003) }\end{array}$ \\
\hline $\begin{array}{l}\text { Upland oak-dominated } \\
\text { broadleaf forest, } \\
\text { Oak Ridge, TN }\end{array}$ & 1996 & & & & 267 & & & & & $\begin{array}{l}\text { Wullschleger } \\
\text { et al. (2001) }\end{array}$ \\
\hline \multirow[t]{4}{*}{ This study } & 2002 & 610 & 80 & 68 & 306 & 453 & 505 & -52 & 0.67 & \multirow[t]{4}{*}{ This study } \\
\hline & 2003 & 859 & 123 & 69 & 299 & 491 & 531 & -40 & 0.61 & \\
\hline & 2004 & 720 & 145 & 72 & 311 & 529 & 525 & 4 & 0.59 & \\
\hline & 2005 & 426 & 34 & 88 & 311 & 433 & 517 & -84 & 0.72 & \\
\hline
\end{tabular}

Annual and growing season values of precipitation $(P)$, canopy interception $\left(I_{C}\right)$, soil evaporation $\left(E_{S}\right)$, canopy transpiration $\left(E_{C}\right)$, sap-flux-based canopy evapotranspiration $\left(\mathrm{ET}_{\mathrm{S}}\right)$, ET estimated through other means (eddy covariance as LE unless noted), lack of closure (LOC) between ETS and $L E$, and the proportion of $E_{C}$ to ET. All values are $m m$ year ${ }^{-1}$, except $E_{C} / E T$ which is unitless.

${ }^{a} E_{\mathrm{C}}$ modeled as component of LE.

${ }^{\mathrm{b}}$ ET estimated through catchment water balance.

component-based and eddy covariance-based ET estimates, after carefully quantifying the evaporation components of $\mathrm{ET}_{\mathrm{S}}$. We developed estimates of evapotranspiration in a mature oak-hickory forest in the southeastern U.S. over a 4year period (2002-2005), which included both a severe drought year and a very wet year. Tree-level sap flux was monitored with thermal dissipation probes, corrected for nighttime fluxes, and scaled to the stand level, accounting for radial patterns, tree size, and species distribution within the eddy covariance footprint and subplots therein, allowing us to separate the effects of signal processing from scaling. Sap fluxscaled transpiration was combined with measured and modeled evaporative losses ( $I_{C}$ and $E_{S}$, respectively), thus accounting for all components of evapotranspiration $\left(\mathrm{ET}_{\mathrm{S}}\right)$, to permit a proper comparison with LE measurements.

\section{Materials and methods}

\subsection{Setting}

The study was conducted at the Duke Forest Ameriflux Hardwood site, Orange County, North Carolina $\left(36^{\circ} 58^{\prime} 41.430^{\prime \prime} \mathrm{N}\right.$, $\left.79^{\circ} 05^{\prime} 39.087^{\prime \prime} \mathrm{W}\right)$. The forest stand is comprised of mixed hardwood species with a maximum age of ca. 80-100 years. Mean canopy height is $25 \mathrm{~m}$ with emergent crown tops extending above $35 \mathrm{~m}$. The stand is dominated by hickories (Carya tomentosa (Poir.) Nutt., C. glabra (P. Mill). Sweet.), yellow poplar (Liriodendron tulipifera L.), sweetgum (Liquidambar styraciflua L.), and oaks (Quercus alba L., Q. michauxii Nutt., Q. phellos L.). Other species that contribute to the mid- and under-story include Carpinus caroliniana Walt., Ostrya virginiana (P. Mill.) K. Koch., Ulmus sp., Cornus florida L., and Cercis canadensis L. Coniferous species including Pinus taeda L. and Juniperus virginiana L. make up a minor component of the over- and understory, respectively.

Long-term (115-year) mean annual precipitation for the area is $1146( \pm 166) \mathrm{mm}$, with $630( \pm 133) \mathrm{mm}$ occurring between April and September (www.ncdc.noaa.gov/). The soil is an Iredell gravely loam and topography is relatively flat with $<4 \%$ slope. The upper $35 \mathrm{~cm}$ is a clay loam with a porosity of $0.54 \mathrm{~m}^{3} \mathrm{~m}^{-3}$. A clay pan with low hydraulic conductivity limits the majority of the rooting zone to approximately $35 \mathrm{~cm}$ (Oren et al., 1998a). Soil depth can be as deep as $2 \mathrm{~m}$ (Richter, personal communication), which overlays bedrock. The site has been the subject of a previous investigation on the transpiration of several canopy and sub-canopy species (Pataki and Oren, 2003). 


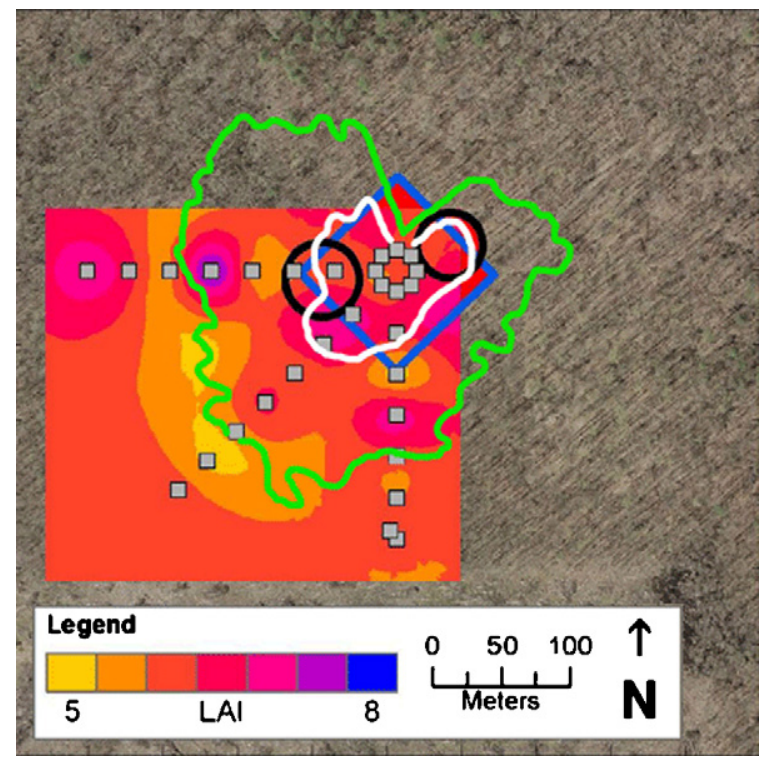

Fig. 1 - Estimated leaf area index (LAI, $\mathrm{m}^{2} \mathrm{~m}^{-2}$ ) for the ca. 6.25 ha overlapping most of the eddy covariance-based flux footprint at the Duke Ameriflux Hardwood Forest near Durham, NC. Black circles represent the boundaries of the wetter (to the west) and drier sap flux plots. The blue diamond delineates the area of the one-hectare plot. Gray squares represent the location of litter traps. Isometric lines represent the probability distribution of the peak of the source-weight function of acceptable eddy covariance flux measurements estimated using the semi-empirical footprint model of Hsieh et al. (2000). The peak of the source weight function lies within the white line $50 \%$ of the 2002-2005 measurement period, and within the green line $95 \%$ of the period. In November 2002, a clearcut was created to the south of the tower, outside of the study area. Fluxes originating from this area were excluded from flux estimates as described by Stoy et al. (2006).

\subsection{Monitoring design and biometric measurements}

An area of approximately 6.25 ha around the AmeriFlux tower (represented by LAI shading in Fig. 1) was identified for this study because it included most of the dynamic flux footprint
(Stoy et al., 2006), estimated using the semi-empirical model of Hsieh et al. (2000). Within this area, two $25 \mathrm{~m}$ radius plots were established for the sap flux study. These two circular plots, henceforth the 'sap flux plots', were chosen to represent a wet (to the west) and a dry micro-site. Species and diameter at breast height (1.45 $\mathrm{m}$ aboveground; $\mathrm{DBH}$ ), down to a minimum diameter of $40 \mathrm{~mm}$, were recorded in the two sap flux plots, and in an entire hectare surrounding the tower (henceforth the 'hectare plot'). Bark thickness $\left(T_{B}\right)$ was measured on several trees and estimated for each individual using the best fit (linear or exponential) with DBH for each species or genus (Table 3). Cross-sectional sapwood area for individual trees $\left(A_{S j}\right)$ was estimated from tree cores of sapwood depth $\left(T_{S w}\right)$ taken at the site, using the equation:

$A_{S j}=\pi\left(\frac{D B H}{2}-T_{B}\right)^{2}-\pi\left(\frac{D B H}{2}-T_{B}-T_{S W}\right)^{2}$

where $\mathrm{DBH}, \mathrm{T}_{\mathrm{B}}$, and $\mathrm{T}_{\mathrm{SW}}$ are in $\mathrm{cm}$. A generalized estimation of $A_{S j}$ for each species was developed using:

$\mathrm{A}_{\mathrm{Sj}}=a \times \mathrm{DBH}^{b}$

where $a$ and $b$ are empirical parameters (Table 3).

Leaf litter was collected in 48 baskets, each with an area of $0.5 \mathrm{~m}^{2}$. Eight baskets were positioned in a circular arrangement, $15 \mathrm{~m}$ from the tower in primary and secondary compass directions. Beyond this $15 \mathrm{~m}$ circle, in the S, SW, and $\mathrm{W}$ directions, seven baskets were placed at $30 \mathrm{~m}$ intervals along transects (Fig. 1), sampling the area most commonly within the tower's footprint (Geron et al., 1997; Stoy et al., 2006). Each sap flux plot also contained 10 baskets, with the second basket along the westward transect doubling as 1 of the 10 in the western plot. Leaves were collected as often as every 2 weeks when litterfall was heaviest, and sorted by species. One-sided surface area of 20-leaf sub-samples of each species was measured using a Digital Image Analysis System (DIAS, Decagon Devices, Inc., Pullman, WA, USA), and the weight of each leaf was obtained after drying $\left(70^{\circ} \mathrm{C}\right.$ for $\left.48 \mathrm{~h}\right)$. A specific leaf area (SLA) of each species was estimated using a linear regression of leaf surface area versus mass with a zerointercept $(p<0.001$, Table 4$)$. Leaf area index (LAI) was estimated by multiplying SLA for each species by the total mass of leaves for that species after similar drying (Table 4).

Table 3 - Allometric relationships from data collected to estimate bark thickness $(\mathrm{mm})$ based on diameter at breast height $(\mathrm{DBH}, \mathrm{cm})$ using either an exponential function $\left(a \times \exp ^{b \times \mathrm{DBH}}\right)$ or linear function $(a \times \mathrm{DBH}+b)$

\begin{tabular}{|c|c|c|c|c|c|c|c|c|c|}
\hline & \multicolumn{5}{|c|}{ Bark thickness } & \multicolumn{4}{|c|}{ Sapwood area regression } \\
\hline & $n$ & Function & $a$ & $b$ & $r^{2}$ & $n$ & $a$ & $b$ & $r^{2}$ \\
\hline \multicolumn{10}{|l|}{ Diffuse porous } \\
\hline L. tulipifera & 19 & Exp & 9.687 & 0.019 & 0.783 & 15 & 0.382 & 2.010 & 0.986 \\
\hline L. styraciflua & 19 & Exp & 3.580 & 0.021 & 0.549 & 16 & 0.246 & 2.202 & 0.971 \\
\hline \multicolumn{10}{|l|}{ Ring porous } \\
\hline All Carya & 11 & Linear & 0.105 & 3.070 & 0.526 & 15 & 1.499 & 1.669 & 0.944 \\
\hline Q. alba and Q. michauxii & & & & & & 11 & 0.612 & 1.737 & 0.987 \\
\hline Q. phellos & & & & & & 9 & 0.284 & 1.932 & 0.948 \\
\hline Combined Quercus & 22 & Linear & 0.199 & 1.322 & 0.826 & & & & \\
\hline
\end{tabular}


Table 4 - Basal area $\left(A_{B}\right)$ and sapwood area $\left(A_{S}\right)$ in $\mathrm{cm}^{2} \mathrm{~m}^{-2}$ ground area for the dry and wet sap flux plots, the hectare plot surrounding the eddy covariance tower, and for the kriged area representing the footprint for measured latent heat flux (LE)

\begin{tabular}{|c|c|c|c|c|c|c|c|c|c|}
\hline & \multicolumn{2}{|c|}{ Dry plot } & \multicolumn{2}{|c|}{ Wet plot } & \multicolumn{2}{|c|}{ Hectare plot } & \multicolumn{2}{|c|}{ LE footprint } & \multirow[t]{2}{*}{ SLA } \\
\hline & $A_{B}$ & $A_{S}$ & $A_{B}$ & $A_{S}$ & $A_{B}$ & $A_{S}$ & $A_{S}$ & LAI & \\
\hline \multicolumn{10}{|l|}{ Diffuse porous } \\
\hline L. tulipifera & 9.80 & 4.97 & 3.22 & 1.63 & 6.29 & 3.18 & 2.14 & 0.83 & 161.8 \\
\hline L. styraciflua & 5.38 & 3.52 & 6.89 & 4.79 & 4.53 & 2.96 & 3.43 & 0.69 & 102.4 \\
\hline Mixed species & 4.33 & 2.52 & 3.25 & 1.87 & 4.17 & 2.35 & 2.44 & 1.78 & 173.3 \\
\hline \multicolumn{10}{|l|}{ Ring porous } \\
\hline All Carya & 8.03 & 4.44 & 4.76 & 2.78 & 6.20 & 3.41 & 2.91 & 2.14 & 131.9 \\
\hline All Quercus & 4.59 & 1.34 & 14.61 & 4.30 & 4.67 & 1.39 & 3.21 & 1.27 & \\
\hline Q. alba & 4.59 & 1.34 & 1.08 & 0.34 & 1.73 & 0.52 & & 0.57 & 112.2 \\
\hline Q. michauxii & 0 & 0 & 6.75 & 2.08 & 1.95 & 0.59 & & 0.59 & 128.9 \\
\hline Q. phellos & 0 & 0 & 6.77 & 1.88 & 0.99 & 0.27 & & 0.11 & 101.9 \\
\hline Mixed species & 0.17 & 0.07 & 3.48 & 1.14 & 1.28 & 0.43 & 0.45 & 0.33 & \\
\hline Plot total & 32.35 & 16.86 & 36.21 & 16.51 & 27.13 & 13.70 & 11.37 & 7.03 & \\
\hline
\end{tabular}

\subsection{Environmental measurements}

Air temperature $\left(\mathrm{T}_{\mathrm{A}}\right)$ and relative humidity $(\mathrm{RH})$ were measured at two-thirds canopy height using HMP35C $\mathrm{T}_{\mathrm{a}} / \mathrm{RH}$ probes (Campbell Scientific, Logan, UT, USA) and were used to calculate vapor pressure deficit $(D)$. Photosynthetically active radiation (PAR) and net radiation were measured above the canopy at $42 \mathrm{~m}$ (see Stoy et al., 2006). Precipitation (P) was measured daily with a rain gauge and partitioned over halfhourly values using data from tipping buckets (TR-525USW, Texas Electronics, Dallas, TX, USA) positioned at the Duke FACE site, $<1 \mathrm{~km}$ away. Throughfall $\left(\mathrm{P}_{\mathrm{T}}\right)$ was measured with 6 rain gauges on the forest floor, manually collected once or twice per week.

Soil moisture $\left(\theta, \mathrm{m}^{3} \mathrm{~m}^{-3}\right)$ was measured with 12 ThetaProbe sensors (Delta-T Devices, Cambridge, UK), four in each of the wet and dry sap flux plots and four next to the eddy covariance tower; at each location two were installed at 5-10 cm depth and two at $20-25 \mathrm{~cm}$. Data were filtered for unrealistic spikes after rain events. Missing data, due to power outages in one of the plots or sensor failure, were gap-filled using the best linear regressions with other working sensors. The regressions were comprised of data on both sides of the gap, equal to the length of the gap in each direction. Periods where $\theta$ reached saturation $\left(0.54 \mathrm{~m}^{3} \mathrm{~m}^{-3}\right)$ or the hygroscopic minimum $\left(0.125 \mathrm{~m}^{3} \mathrm{~m}^{-3}\right)$ were identified and the recorded $\theta$ values for each sensor were rescaled to match these values (Schäfer et al., 2002).

\subsection{Sap flux measurement}

Granier-type, heat dissipation sensors were used to monitor $J_{S}$ (Granier, 1987). Each pair of sensors was $20 \mathrm{~mm}$ in length and the heated element received a constant power of $0.2 \mathrm{~W}$. Five $\mathrm{L}$. tulipifera and L. styraciflua were equipped in each plot. In addition, five $C$. tomentosa and $Q$. alba were equipped in the dry sap flux plot, and five Q. michauxii and Q. phellos in the wet plot. These species were selected because they comprised the majority of sapwood area at the site, and because fluxes monitored on several other species in this and a nearby site were similar for a given xylem type (i.e. within ring- or diffuseporous groups; Oren and Pataki, 2001; Pataki and Oren, 2003; Wullschleger et al., 2001). To quantify the radial profile of sap flux density, sensors were installed at $20-\mathrm{mm}$ depth intervals based on the expected sapwood depth. Tree DBH and sensor depths are listed in Table 5.

Sap flux sensors measure the temperature differential $(\Delta T)$ between the paired heated and unheated probes. $\Delta \mathrm{T}$ (recorded in $\mathrm{mV}$ ) for each sensor pair was measured at $30 \mathrm{~s}$ intervals and 30 min averages were stored on a CR23X datalogger (Campbell

Table 5 - Diameter at breast height (DBH, cm) and

maximum sap flux sensor depth $(\mathrm{mm})$ for trees sampled at the wet and dry sites

\begin{tabular}{lccccc} 
Dry site & DBH & Depth & Wet site & DBH & Depth \\
\hline L. tulipifera & 65.4 & $40-60$ & L. tulipifera & 59.8 & $40-60$ \\
& 44.4 & $40-60$ & & 38.7 & $20-40$ \\
& 42.0 & $40-60$ & & 37.7 & $20-40$ \\
& 26.4 & $20-40$ & & 36.0 & $20-40$ \\
& 16.1 & $20-40^{\mathrm{a}}$ & & 26.6 & $20-40$ \\
L. styraciflua & 48.0 & $40-60$ & L. styraciflua & 55.6 & $20-40$ \\
& 47.4 & $40-60$ & & 42.8 & $20-40$ \\
& 35.0 & $40-60$ & & 37.5 & $20-40$ \\
& 24.3 & $20-40$ & & 34.4 & $20-40$ \\
C. tomentosa & 19.7 & $20-40$ & & 21.1 & $20-40$ \\
& 58.4 & $40-60$ & Q. michauxii & 54.4 & $20-40^{\mathrm{a}}$ \\
& 54.4 & $40-60$ & & 47.6 & $20-40^{\mathrm{a}}$ \\
& 25.1 & $20-40$ & & 30.2 & $20-40^{\mathrm{a}}$ \\
& 20.0 & $20-40$ & & 20.1 & $0-20$ \\
& 12.7 & $0-20$ & & 16.1 & $0-20$ \\
Q. alba & 57.7 & $20-40^{\mathrm{a}}$ & Q. phellos & 63.6 & $20-40$ \\
& 43.1 & $20-40^{\mathrm{a}}$ & & 53.5 & $20-40$ \\
& 30.8 & $0-20$ & & 44.0 & $20-40^{\mathrm{a}}$ \\
& 16.4 & $0-20$ & & 43.2 & $20-40^{\mathrm{a}}$ \\
& 13.7 & $0-20$ & & 43.1 & $20-40^{\mathrm{a}}$ \\
\hline
\end{tabular}

${ }^{a}$ Deepest sensor required correction due to contact with nonconductive tissue (Clearwater et al., 1998). 
Scientific, Logan, UT, USA). To convert these data into water flux, the following equation is used:

$J_{\mathrm{S}}=119 \times\left(\frac{\Delta \mathrm{T}_{\max }}{\Delta \mathrm{T}}-1\right)^{1.23}$

where $\Delta T_{\max }$ is the maximum temperature differential at which sap flux is zero (Granier, 1987). In generating sap flux estimates, we accounted for sensor contact with poorly conductive xylem; sap flux is underestimated if a portion of the sensor is in contact with heartwood (Lu et al., 2004). Although corrections were made to account for flux underestimation by sensors so positioned (Clearwater et al., 1998), the exact proportion of a particular sensor's length that extends into non-conductive sapwood cannot be determined without a destructive harvest; with other ongoing studies at the site, determination through such harvest could not be made. Inaccurate estimates of inactive sapwood in contact with sensors can lead to large under-or over-estimates of sap flux after corrections are implemented. Thus, data were discarded if corrected fluxes were outside two standard deviations from the mean of similar sensors (species and depth) and replacement sensors were installed in new positions on the same tree. In all, 8 of the 83 sensors were partially in contact with heartwood; data from two sensors were considered unreasonable resulting in sensor replacement. Table 5 details the sensors that underwent corrections based on Clearwater et al. (1998) and were considered acceptable.

To account for potential nocturnal fluxes due to both transpiration and recharge, we selected the highest daily $\Delta \mathrm{T}$ to represent $\Delta T_{\max }$ if two conditions are satisfied simultaneously: (a) the average, minimum $2-\mathrm{h} \mathrm{D}$ is $<0.05 \mathrm{kPa}$, thus assuring that water loss to the atmosphere is negligible, and (b) the standard deviation of the four highest $\Delta T$ values is $<0.5 \%$ of the mean of these values; such stable measurement of maximum $\Delta \mathrm{T}$ ensures that recharge of water above the sensor height is completed or negligible. In our sap flux time series, zero-flux nighttime conditions were often not met for several consecutive days.

We developed a modified method for scaling tree-level transpiration that accommodates changes in $J_{S}$ with depth. Sap flux density in the outer $20 \mathrm{~mm}$ did not vary with tree diameter for any of the species (minimum $p>0.60$ ), which allowed to combine these data into a time series of mean $J_{\mathrm{Si}}$ (where subscript $i$ represents an individual species) in the outer xylem. Measured daily $J_{\mathrm{Si}}$ values from deeper sensors in each tree were normalized by the mean $J_{\mathrm{Si}}$ of all outer sensors. These normalized values were fit to a Gaussian function, $y=\exp \left(-0.5(x-a / b)^{2}\right)$, where $y$ is the normalized flux and $x$ is the relative depth of the sensor's center point in the sapwood, normalized between 0 at the cambium and 1 at the sapwoodheartwood interface (SigmaPlot 2002, version 8.02, SPSS Inc.). For species in which the peak of the curve did not occur at the edge of the sapwood-cambium interface, a maximum rate of normalized sap flux (i.e. 1) was assumed between the position of the peak and the cambium. Integrated whole-tree $J_{S}$ was estimated using Pappus's second theorem for calculating the volume of a rotated geometric solid:

$V_{j}=2 \pi c_{j} A_{F j}$

where $A_{F j}$ is the area beneath the fitted curve for an individual tree, $c_{j}$ is the distance from the center of that tree to the centroid of the curve, and $V_{j}$ is a volume that represents the effective amount of highly conductive sapwood. We can consider this volume with respect to time $\left(\mathrm{cm}^{3} \mathrm{~s}^{-1}\right)$ in terms of a velocity $\left(\mathrm{cm} \mathrm{s}^{-1}\right)$ multiplied by an area $\left(\mathrm{cm}^{2}\right)$ where the velocity is $J_{\mathrm{S}}\left(\mathrm{cm}^{3} \mathrm{H}_{2} \mathrm{O}\right.$ per $\mathrm{cm}^{2} \mathrm{~s}^{-1}$, or $\left.\mathrm{cm} \mathrm{s}^{-1}\right)$ and the area is $A_{\mathrm{Sj}}$. Thus, multiplying $V_{j}$ by the mean, outer-xylem $J_{S i}$ for that species yields whole-tree transpiration.

Occasional sensor failure and power outage in a particular plot produced missing data. Data before and after each gap was fitted to a power function with all functioning sensors and gapfilled using the best fit against a functioning sensor. The best fitting sensor was identified based on $r^{2}$, closeness to linearity (i.e. exponential parameter closest to 1), and the distribution of residuals. In all, $40 \%$ of growing season data was gap-filled.

\subsection{Stand-level transpiration}

Using allometric relationships, $A_{S}$ was estimated for the area covered by the two sap flux plots and the hectare plot (Table 3). Large differences were observed among the three estimates of $A_{S}$, either for a particular species or in total (Table 4), with likely effect on stand-level transpiration estimates. To allow comparison of stand-level component-based estimate of evapotranspiration with LE from the larger area representing the eddy covariance footprint, it was necessary to expand the spatial scale of our sap flux study plots.

We first established a linear relationship between speciesspecific LAI data from the 10 litter baskets in the hectare plot and the total $A_{S}$ within an optimized distance (based on $r^{2}$ ) from each basket. Combining all species from the Carya and Quercus genera produced the best fits, $A_{S}=3.287 \times \mathrm{LAI}+0.166$ $\left(r^{2}=0.914 ; p<0.0001\right)$ and $A_{S}=1.428 \times \mathrm{LAI}+0.363\left(r^{2}=0.902 ;\right.$ $p<0.0001)$, respectively, where LAI is in $\mathrm{m}^{2} \mathrm{~m}^{-2}$ and $A_{\mathrm{S}}$ is in $\mathrm{cm}^{2} \mathrm{~m}^{-2}$ of ground area. The relationship for L. tulipifera was $A_{S}=5.028 \times \mathrm{LAI}+0.157\left(r^{2}=0.758 ; p=0.0011\right)$. No suitable relationship was found for $L$. styraciflua and for the less abundant and sub-canopy species, so the mean $A_{S}$ (3.43 and $2.89 \mathrm{~cm}^{2} \mathrm{~m}^{-2}$, respectively) was applied over the entire site. Species-specific LAI at each of the 29 transect trap locations was converted to a spatial map for the entire stand using simple kriging (ArcGIS 9, ESRI, Redlands, CA; Fig. 1). Using the relationships or averages, we used LAI to estimate $A_{S}$ across the entire kriged area. Inter-annual mean maximum LAI at the site was $6.3( \pm 0.4) \mathrm{m}^{2} \mathrm{~m}^{-2}$. The two sap flux plots and the hectare plot were positioned in an area with LAI similar to the EC footprint $\left(6.8 \pm 0.3 \mathrm{~m}^{2} \mathrm{~m}^{-2}\right)$, yet the contribution of each species or genera varied among some of these areas. The LE footprint included areas ranging in LAI by as much as $\pm 1.7 \mathrm{~m}^{2} \mathrm{~m}^{-2}$ from the mean (Fig. 1).

For the two sap flux plots and the hectare plot we summed whole-tree transpiration to estimate $E_{C}$. Across the larger domain, representing the eddy covariance flux footprint, $E_{C}$ was based on scaling with LAI-based $A_{S}$ estimate:

$E_{C}=\sum_{i}\left(E_{\text {Cih }} \times \frac{A_{S i}}{A_{\text {Sih }}}\right)$

where $E_{C i h}$ is $E_{C i}$ for the hectare plot, $A_{S i h}$ is sapwood area for species $i$ in the hectare plot, and $A_{S i}$ is sapwood area for the 
entire stand. The hectare plot was used as a basis for scaling because trees in this plot were a more complete representation of the species and range of size classes found in the larger eddy covariance footprint than the trees in the smaller sap-flux plots.

In scaling, the mean sap flux of the three monitored Quercus species was employed for unmonitored Quercus species ( $Q$. coccinea and $Q$. prinus, together comprising $3 \%$ of $A_{S}$ ). Sap flux of C. tomentosa was used for unmonitored Carya species (C. glabra and C. ovata; $15 \%$ of $A_{S}$ ). Unmonitored diffuse-porous and ringporous genera were estimated to contribute $20 \%$ of stand $A_{S}$ in the eddy covariance footprint. This sapwood was partitioned between the two xylem types based on their proportions in the hectare plot (Table 4). The average sap flux of Quercus and Carya was employed to estimate transpiration of the other ring-porous genera, and that of L. styraciflua and L. tulipifera of the other diffuse-porous genera. Using the sap flux of either of the latter species alone affected stand transpiration $\left(E_{C}\right)$ during the growing season by an average of $2.3( \pm 0.08) \mathrm{mm}$, or less than $1 \%$ of total growing season transpiration, demonstrating that the $E_{C}$ estimate is reasonably robust to the choice of representative species.

\subsection{Evaporation losses}

Latent heat flux (LE) measured with eddy covariance (expressed in $\mathrm{mm} \mathrm{H}_{2} \mathrm{O}$ ) should balance against the components of evapotranspiration such that:

$\mathrm{LE}=\mathrm{I}_{\mathrm{C}}+\mathrm{E}_{\mathrm{S}}+\mathrm{E}_{\mathrm{C}}$,

where $I_{C}$ is canopy interception and $E_{S}$ is evaporation from the forest floor and soil surface.

LE was measured using the eddy covariance method comprising of a triaxial sonic anemometer (CSAT3, Campbell Scientific, Logan, UT, USA) and an open-path infrared gas analyzer (IRGA, LI-7500, Li-Cor, Lincoln, NE, USA) positioned $39.8 \mathrm{~m}$ above the forest floor. Vertical wind velocity, temperature, and scalar concentrations of $\mathrm{H}_{2} \mathrm{O}$ were sampled at $10 \mathrm{~Hz}$ and averaged for half-hour periods. For processing, density corrections, and analyses of the seasonal and dynamics of components of the energy balance including its closure, see Stoy et al. (2006). The path between transducers in the sonic anemometer or optical length in the open path IRGA may be blocked during and immediately following rain events, and correctly identifying these data 'gaps' is required to ensure that long-term sums are correct (Falge et al., 2001).

$I_{C}$ was estimated by subtracting $P_{T}$ from $P$ measured between collection periods. An exploratory investigation on the proportion of $P$ reaching the forest floor as stemflow was conducted over a 2-month period with varying LAI. The exploratory study was conducted on six trees representing the most abundant species and a range of sizes. The rate of stemflow, normalized by tree circumference, was unrelated to tree size $(p>0.3)$, consistent with Granier et al. (2000). When scaled to the stand, stemflow was estimated to contribute $<1 \%$ of annual precipitation and was excluded from further consideration. To convert weekly and bi-weekly $I_{C}$ measurement to continuous, half-hourly values, $P_{\mathrm{T}}$ accumulated between measurements was distributed based on a normalized time series of $P$. For dates of missing $P_{T}$ measurements, estimates for each throughfall gauge were made using a linear regression with $P$ (Table 6). To avoid mischaracterizing interception associated with multiple, small rain events as a single, large rain event, data for these regressions were filtered to include collection periods in which only one precipitation event occurred.

$E_{S}$ was not measured directly. The decoupling coefficient (Jarvis and McNaughton, 1986) approaches zero in winter (Stoy et al., 2006), indicating a strong coupling between surface conductance and evaporative demand. Thus, $E_{S}$ was estimated using the wintertime (DOY 300-75) relationship between $D$ and LE from the eddy covariance system. We excluded data from the first 3 days after precipitation events to avoid double-counting $\mathrm{I}_{\mathrm{C}}$ and discounted the small amounts of water loss through the bark surface (available from scaled sap flux measurements) to avoid double-counting $E_{C}$. We found significant $(p<0.001)$ differences between the power function in 2002 and the subsequent years (Table 6). This difference was possibly due to inter-annual variation in surface water availability, generated by consecutive growing season droughts in 2001 and 2002. Peak values in $E_{S}$ showed maximum cross-correlation with peak $D$ values at a 3 -h time lag, which was incorporated into the regression to eliminate a pattern in the residuals. We tested these estimates of $E_{S}$ by comparing them with nighttime LE during the growing season, using non-gap-filled data and again avoiding periods after precipitation. We found no significant difference between estimated $E_{\mathrm{S}}$ and measured nighttime LE $(p>0.6)$.

\section{Results and discussion}

We focus first on methodological aspects of sap flux measurements, then analyze our procedure for scaling sap

Table 6 - Parameters for equations used to estimates components of evaporation

\begin{tabular}{lccc} 
& $a$ & $y_{0}$ & $r^{2}$ \\
\hline Canopy throughfall & & & \\
Gauge 1 & 0.8675 & -0.5272 & 0.90 \\
Gauge 2 & 0.7886 & -0.4780 & 0.94 \\
Gauge 3 & 0.9000 & -0.6791 & 0.94 \\
Gauge 4 & 0.9040 & -0.4229 & 0.92 \\
Gauge 5 & 0.8469 & -0.4582 & 0.86 \\
Gauge 6 & 0.9366 & -0.4670 & 0.94 \\
& & & \\
& & $b$ & \\
Soil evaporation & & & \\
2002 & 0.0066 & 1.4320 & 0.09 \\
2003-2005 & 0.0123 & 1.3003 & 0.14 \\
Canopy transpiration & & & \\
Winter (LAI < 1) & 0.3114 & 0.3305 & 0.24 \\
\hline
\end{tabular}

Canopy interception $\left(I_{C}\right)$ was estimated as precipitation $(P)$ minus measured throughfall $\left(P_{\mathrm{T}}\right)$. Missing $P_{\mathrm{T}}$ data were estimated for each throughfall gauge using the linear function $P_{T}=a P+y_{0}$. Soil evaporation $\left(E_{S}\right)$ used a power function: $E_{S}=a D^{b}$, where $D$ is vapor pressure deficit. Winter canopy transpiration $\left(E_{C}\right)$ was estimated using a power function: $E_{C}=a D_{Z}^{b}$ where $D_{Z}$ is day-length-normalized vapor pressure deficit. All regressions are significant at $p<0.0001$. 

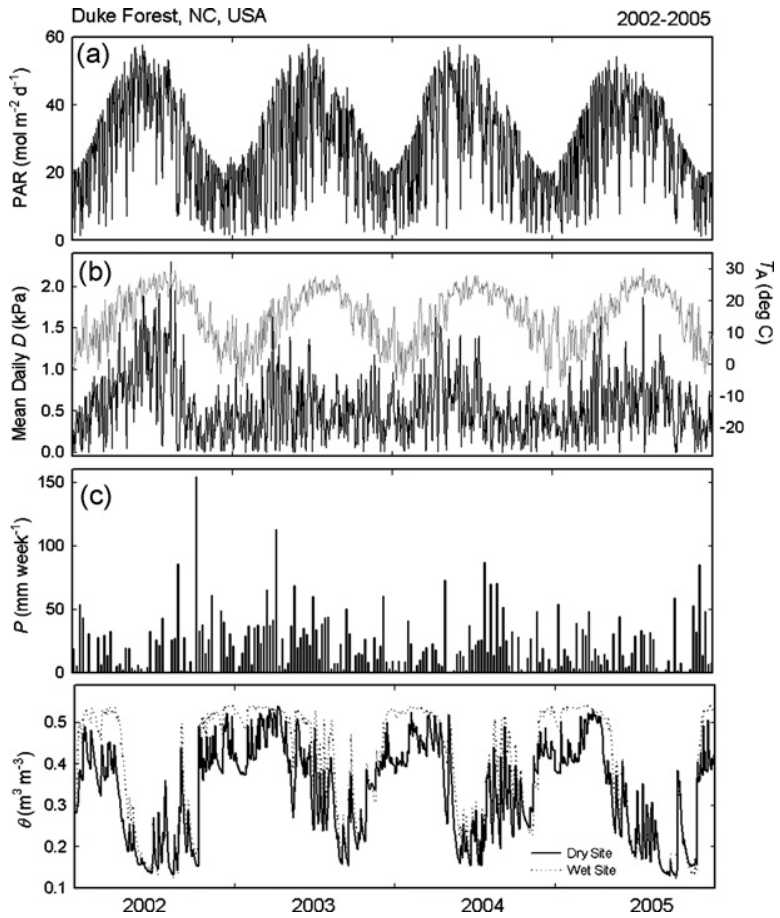

Fig. 2 - Environmental variables measured at hardwood stand at Duke Forest, 2002-2005. (a) Above-canopy photosynthetically active radiation (PAR), (b) daily mean mid-canopy vapor pressure deficit $(D)$ and air temperature $\left(T_{A}\right)$, (c) weekly totals of precipitation $(P)$, and $(d)$ volumetric soil moisture $(\theta)$ for the wet and dry sap flux plots.

flux measurements to the canopy level and conclude by evaluating the contribution of individual components to the closure of stand-level evaporation balance. We note that high variability in intra- and inter-annual weather (Fig. 2) presents an opportunity to use our sap flux processing and scaling methodology over a wide range of environmental conditions.

\subsection{Revised methodology for sap flux signal processing}

The revised approach for converting sap flux data by selecting $\Delta T_{\max }$ only during nights with stable $\Delta T$ and $D \approx 0 \mathrm{kPa}$ accounts for both the seasonal shifts of $\Delta T_{\max }$, due to the hydration state of the sapwood, and the combined effects of nocturnal water loss from leaves and recharge of water above sensor height. With the revised processing in place, sap flux was frequently observed throughout nighttime hours. A representative set of diurnal courses (Fig. 3) illustrates a fivefold increase in nocturnal $J_{S}$ for all species except $L$. styraciflua, which increased by $\sim 50 \%$. Revised daytime maximum $J_{S}$ estimates were also higher during this sample period, showing increases of nearly $20 \%$ in L. tulipifera and Quercus spp. and nearly $35 \%$ in C. tomentosa. The smaller increase in nocturnal $J_{S}$ of $L$. styraciflua during this period did not lead to a noticeable change in daytime $J_{S}$. Later we discuss the effect of the increase in $J_{S}$ of some of the most prevalent species on stand $E_{C}$.

Daley and Phillips (2006) used sap flux sensors at two heights on the stem along with leaf-level gas exchange measurements to detect and partition nocturnal fluxes into recharge and conductance in three deciduous species. In their study, shade-intolerant, early-successional paper birch (Betula paprifera) exhibited the highest nocturnal fluxes, which were almost exclusively due to transpiration. Nocturnal fluxes of red oak (Quercus rubra) and red maple (Acer rubrum), more shade-tolerant species, were used almost entirely to re-supply water to the trunk. In our study, early-successional species showed lower nighttime $J_{S}$ than late-successional species (early-successional L. tulipifera and L. styraciflua $J_{S}$ of $13.1 \pm 0.2$ and $10.1 \pm 4.4 \mathrm{~g} \mathrm{H}_{2} \mathrm{O} \mathrm{m}^{-2}$ sapwood area per night, respectively, and late-successional $C$. tomentosa and Quercus spp. $21.6 \pm 5.8$ and $21.7 \pm 4.7 \mathrm{~g} \mathrm{H}_{2} \mathrm{O} \mathrm{m}^{-2}$ sapwood area per night, respectively). Our design did not permit species-specific partitioning of these nocturnal fluxes into recharge versus transpiration; however, Dawson et al. (2007) observed nocturnal transpiration across a wide range of woody species. We did find that the large absolute differences in nocturnal $J_{\mathrm{S}}$ translated to similar proportional changes in estimated total growing season $E_{C i}$, amounting to $\sim 11 \%$ in early-successional species and $\sim 14 \%$ in late-successional species.

Species using nocturnal water uptake to supply transpiration more than recharge show a rapid rise in sap flux with increasing D (Oren and Pataki, 2001). We found such a trend based on mean nighttime $J_{S}$ and $D$ after days without rainfall (data not shown). Following rain events, nocturnal sap flux exhibited much more erratic responses to $D$. And although the majority of afternoons following rains were characterized by low $D$ and low $J_{S}$, the majority of these nights had high $J_{S}$ when compared to the expected flux based on the sensitivity to $D$ as observed on dry days. These large nocturnal fluxes following drought-breaking rains represent recharge of stored water progressively depleted over entire drying cycles.

During a particular drying cycle, the amount of water recharging trees at night has been shown to increase with soil moisture depletion (Phillips et al., 1996), causing recharge to account for an increasing proportion of daily transpiration (Oren et al., 1998b). In this study, average nocturnal flux was significantly higher $(p<0.001)$ when $\theta<0.20 \mathrm{~m}^{3} \mathrm{~m}^{-3}$, a value shown to limit stomatal conductance and transpiration in this stand (Pataki and Oren, 2003). Thus, as soil drying intensifies during a cycle, more water is taken up each night. Our study does not permit a species-specific evaluation of whether the increased nocturnal flux with soil drying represents increasing amount of water drawn from storage each day and recharged each night, or increasing nocturnal water loss from leaves driven by increasing $D$ with the progression of drying cycles. However, we show later that, on average for the stand and over the 4-year study, nightly water uptake was used to both supply water lost from leaves and recharge the storage. Considering that the forest is composed nearly equally of shade-tolerant and shade-intolerant species, this finding is consistent with that of Daley and Phillips (2006).

\subsection{Scaling sap flux measurements to the eddy covariance footprint}

Sap flux density can be highly variable among individuals of a given species, necessitating a large number of replicates to attain an accurate estimate of the mean flux (Oren et al., 


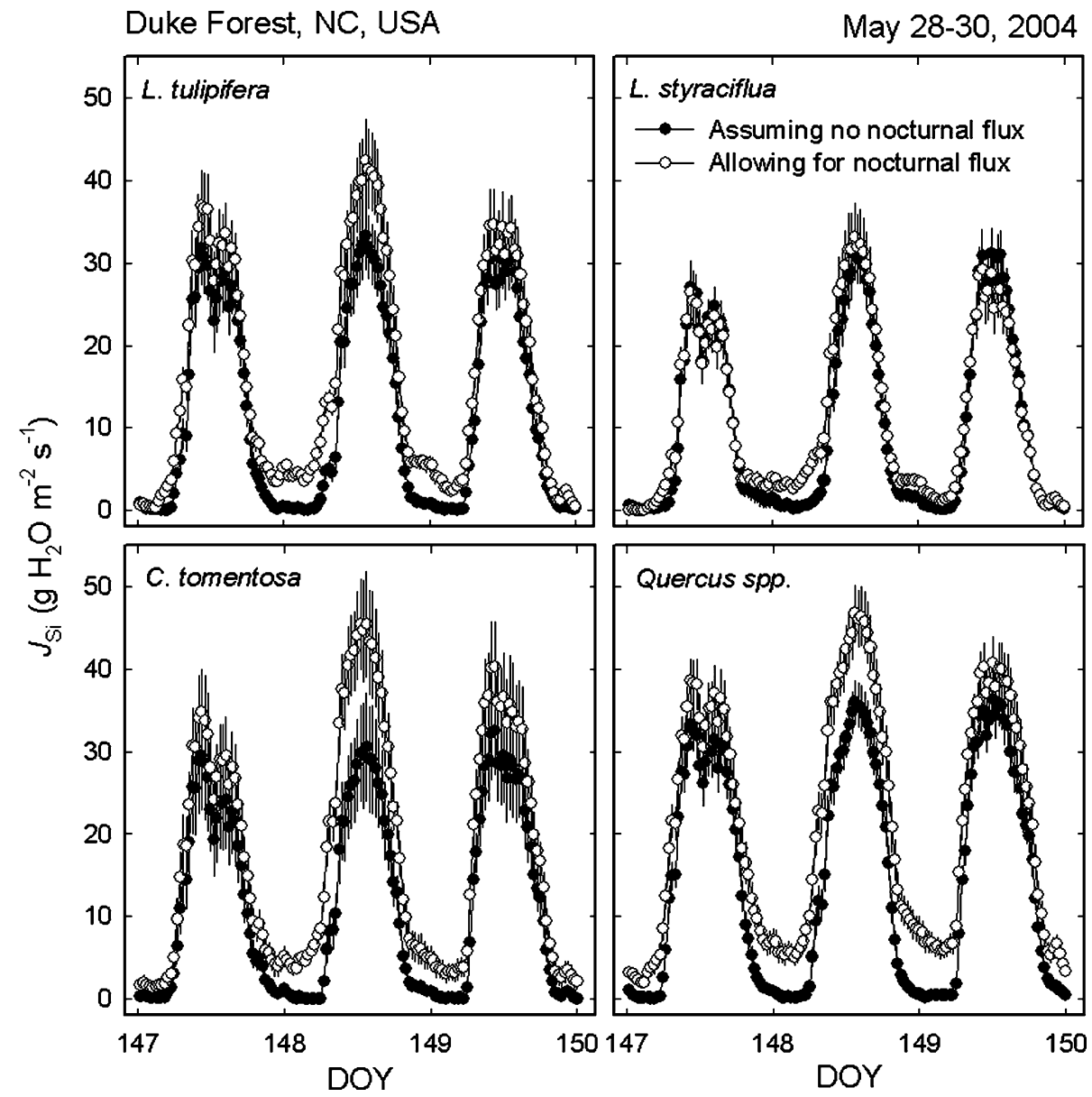

Fig. 3 - Sap flux density by species or genus $\left(\mathrm{Jsi}_{\mathrm{si}}\right)$ for 3 days during the 2005 growing season with nighttime $\mathrm{D}>0.05 \mathrm{kPa}$. Black circles show data converted using a method that establishes a baseline value under the assumption that fluxes drop to zero every night. Open circles show data converted with the revised method in which the $\Delta T_{\max }$ baseline allows for nighttime flux. Error bars represent 1 S.E.

1998b). This is difficult to achieve in species-rich forests, where increasing replicate numbers can be achieved only by setting more plots spaced further apart, each requiring power and a full complement of environmental sensors to capture the spatial variability in conditions. Kumagai et al. (2005) recommended monitoring a minimum of six trees to account for random variation. We were able to position our dataloggers such that five individuals of each species in each plot were monitored. Furthermore we found that neither L. tulipifera nor L. styraciflua, the two species sampled in both the wet and dry plots, showed plot-level differences in daily $J_{\mathrm{Si}}(p>0.1)$, allowing to pool the individuals of each species (thus producing $n=10$ ). Similarly, the three monitored Quercus species showed similar daily $\mathrm{J}_{\mathrm{Si}}(p>0.1)$ allowing to pool the individuals of this genus $(n=15)$. This left only $C$. tomentosa $(n=5)$ with less than the minimum recommended sample size.

Radial patterns in flux were assessed based on sensors installed at different depths. Radial sap flux trends for ringporous and diffuse-porous species were consistent with some but not all studies (Phillips et al., 1996; Wullschleger and Norby, 2001). The $J_{\text {Si }}$ pattern in the sapwood of diffuse-porous species, $L$. tulipifera and L. styraciflua, as well as ring-porous C. tomentosa, was best described as Gaussian (Fig. 4). Nevertheless, based on a synthesis of studies on radial patterns in flux (Phillips et al., 1996), sapwood between the cambium and the peak of the Gaussian curve was assumed to transpire at the maximum rate (represented by the dashed line in Fig. 4). Regressions using sensors' relative depth in sapwood, rather than absolute depth in sapwood, had higher $r^{2}$ values and showed similar patterns in trees of different diameters. None of the three Quercus species showed a radial pattern in sap flux and were assumed to have uniform flow throughout the sapwood, similar to results from $Q$. alba (Phillips et al., 1996). Ring-porous species with thin sapwood are especially prone to errors in $J_{\mathrm{S}}$ estimates if the sensors extend into heartwood (Clearwater et al., 1998; Wullschleger and Hanson, 2006), can show a sharp decrease over small intervals within the sapwood (see Phillips et al., 1996), and may support flow even beyond the visually determined sapwood (Poyatos et al., 2007). These factors conspire to produce a large degree of variation among individuals of ring-porous species, necessitating a higher number of replicates to attain a similar degree of accuracy than is required for diffuse-porous and non-porous species (Oren et al., 1998b). 


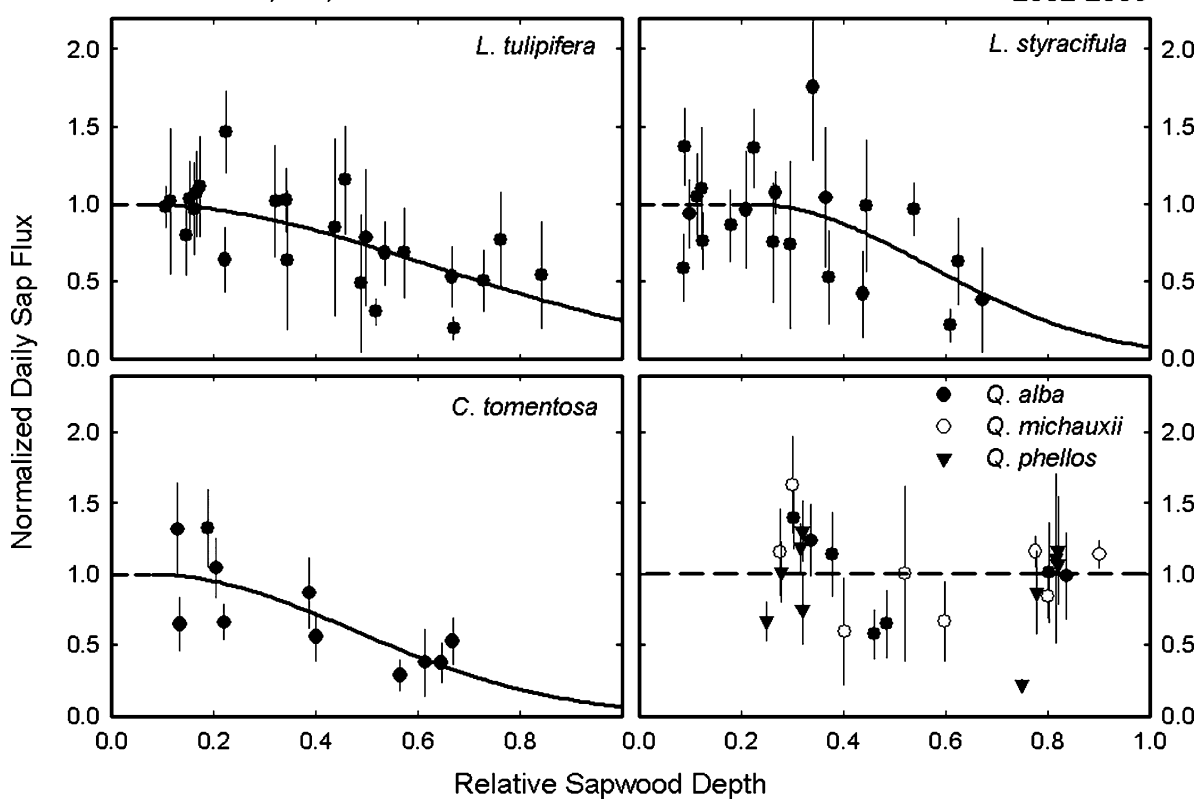

Fig. 4 - Radial profiles of sap flux $\left(\mathrm{J}_{\mathrm{si}}\right)$ based on relative sapwood depth (beginning in the cambium interface) and normalized mean sap flux. Data were fitted to a Gaussian equation. The equation for normalized daily sap flux for L. tulipifera was $\exp \left(-0.5(x-0.055 / 0.568)^{2}\right)$ (adjusted $\left.r^{2}=0.37 ; p=0.003\right)$, L. styraciflua was $\exp \left(-0.5(x-0.222 / 0.343)^{2}\right)\left(\right.$ adjusted $r^{2}=0.21 ;$ $p=0.047)$, and C. tomentosa was $\exp \left(-0.5(x-0.078 / 0.396)^{2}\right)$ (adjusted $\left.r^{2}=0.48 ; p=0.029\right)$, where $x$ is the relative sapwood depth. Dashed lines in the top two panels indicate sections where the peak of the curve did not occur at the sapwoodcambium interface and where a maximum rate of normalized sap flux (i.e. 1.0) was assumed. The horizontal dashed line in the Quercus spp. panel indicates that no radial pattern was observed in any species and a uniform sap flux was assumed throughout the sapwood.

Further complication in scaling may occur when the proportion of sap flux measured in inner sensors varies with environmental conditions and seasons, requiring sufficient data to quantify the changing patterns. In Pinus taeda this ratio decreased with soil water availability (Phillips et al., 1996), and was near unity in winter, reaching a minimum in mid-growing season (Schäfer et al., 2002). Here, despite large inter-annual variability in growing season soil moisture, the relationships between radial depth and flux were similar under drought and non-drought conditions within a year, and did not change among years $(p>0.1)$. Thus, transpiration for each tree within our sap flux plots and the hectare plot was estimated based on Eq. (4), using the mean species- or genus-specific flux in the outer xylem, the radial sap flux patterns (Fig. 4), and sapwood area estimated based on allometric equations (Table 3).

Species-specific values of transpiration $\left(E_{C i}\right.$, where $i$ represents an individual species; Fig. $5 a$ and $b$ ) for the hectare plot, obtained by summing individual tree transpiration, were normalized by $A_{S i}$ in that plot then multiplied by the EC footprint $A_{S i}$ (Table 4). Values of $E_{C i}$ were combined to produce $E_{C}$ (Fig. 5c). Growing season (April-October) $E_{C}$ was very consistent among years, comprising approximately $65 \%$ of growing season $\mathrm{ET}_{\mathrm{S}}$ (Table 2), despite large differences in the amount and timing of precipitation (Fig. 2c). Over the growing season, Quercus spp. accounted for $38 \%$ ( $\pm 2 \%$ among the 4 years) of total $E_{C}$. The rest of $E_{C}$ was contributed by Carya spp., L. styraciflua, and L. tulipifera at $19( \pm 2), 16( \pm 1)$, and $11( \pm 1) \%$, respectively. Other species, which included most understory and some overstory trees, accounted for the remaining 16 $( \pm<1) \%$ of $E_{C}$. The order of contribution was poorly related to the order of the species or genus $A_{S i}$ (Table 4), reflecting the differences observed in $J_{\mathrm{Si}}$, as observed in another study in a similar forest (Wullschleger et al., 2001).

Pataki and Oren (2003) measured sap flux in a different plot in the same stand in 1997, and found lower growing season $E_{C}$ (264 mm), similar to an estimate at a nearby, upland broadleaf stand (278 mm, Oren and Pataki, 2001). Basing their scaling on the findings of Phillips et al. (1996), these previous studies did not account for differential radial flow patterns, which would tend to overestimate $E_{C}$ (Ford et al., 2004). However, their plots were positioned in areas with lower sapwood area density than this study, which should somewhat compensate. Indeed, estimates from the previous studies are very similar to our estimates before we accounted for nighttime fluxes $(279 \pm 11 \mathrm{~mm})$. Thus, we conclude that the previous studies underestimated $E_{C}$ because they failed to account for the effects of nocturnal fluxes in data processing. Other estimates for similar sites show similar annual $E_{C}$ as well as the proportion of $P$ used as $E_{C}$ (Table 2).

Sap flux measurements continued through the winter after the loss of leaves and showed low, but detectable, fluxes that may be attributed to water loss from the bark surfaces (Kozlowski, 1943; Oren and Pataki, 2001; Weaver and Mogensen, 1919). The half-hourly fluctuations in $\Delta \mathrm{T}$ were often of a similar magnitude to the diel fluctuations, making it difficult to identify a reliable $\Delta T_{\max }$ for many winter days. Therefore, $E_{C}$ 
Duke Forest, NC, USA
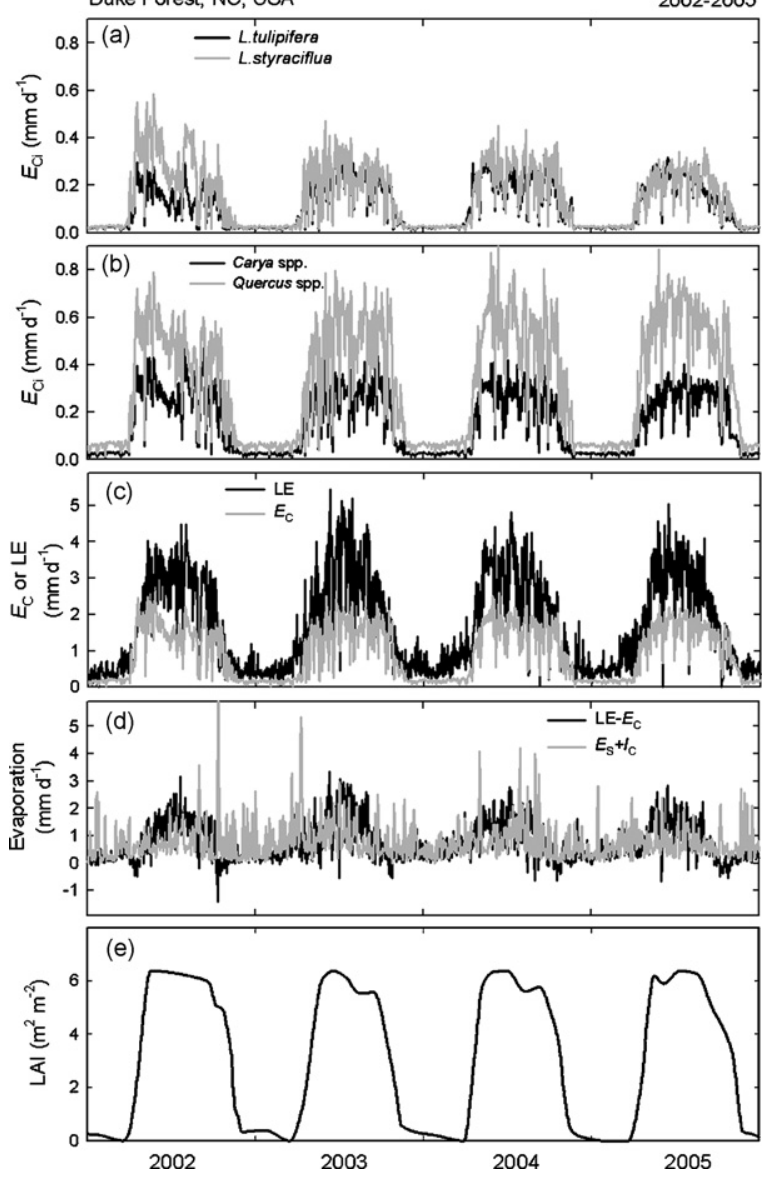

Fig. 5 - Stand-level fluxes over the four study years. (a) and (b) show sap flux-scaled canopy transpiration by species $\left(E_{\mathrm{Ci}}\right),(\mathrm{c})$ shows total sap flux-scaled canopy transpiration $\left(E_{C}\right)$ and eddy covariance-measured latent heat flux (LE), (d) estimates for the remaining components of stand evapotranspiration (soil evaporation, $E_{S}$ ) plus canopy interception ( $I_{C}$, plotted as a 3-day moving average) compared to the difference $L E-E_{C}$, (e) leaf area index (LAI, $\mathrm{m}^{2} \mathrm{~m}^{-2}$ ).

was modeled for winter months by combining reliable data from all trees using a power function with day-lengthnormalized vapor pressure deficit $\left(D_{Z}\right.$; Table 6$)$. This function was used to estimate $E_{C}$ during winter months (DecemberMarch, classified by LAI $<1$ ) for the entire stand, which averaged $20( \pm 0.8) \mathrm{mm}_{\text {year }}{ }^{-1}$, about $6 \%$ of annual $E_{C}$. Mean winter $E_{C}$ was $0.17( \pm 0.01) \mathrm{mm} \mathrm{d}^{-1}$, higher than that previously reported in this area for Acer rubrum and Q. alba $\left(0.07 \mathrm{~mm} \mathrm{~d}^{-1}\right.$, Pataki and Oren, 2003), most like due to accounting for nocturnal sap flux. Wintertime $E_{C}$ was allocated among species based on their proportion of growing season $E_{C}$.

The large footprint of LE measurements above tall forests can present challenges for scaling sap flux as a component of $\mathrm{ET}_{\mathrm{S}}$ at a comparable scale. As a reminder, we scaled sap flux to three areas of the stand based on $A_{S}$ obtained from the inventory in (1) the two sap flux plots, (2) the hectare plot around the tower, and (3) from LAI in the approximately $250 \mathrm{~m} \times 250 \mathrm{~m}$ area representing most of the eddy covariance footprint (Fig. 1). Estimated annual $E_{\mathrm{C}}$ for the eddy covariance footprint was $338( \pm 7) \mathrm{mm}$ (Table 2$), 8 \%$ lower than for the two sap flux plots due to an overrepresentation of Quercus in the wet sap flux plot (Table 4), and $17 \%$ higher than the hectare plot due to an under-representation of this genus in the area immediately surrounding the tower. Thus, despite the similarity of average LAI among these sample areas, nonuniform species distribution in the forest (affecting the scaling $A_{S i}$ ) combined with species differences in sap flux produced substantially different estimates of $E_{C}$. A proper comparison of $E_{S}$ with LE requires scaling sap flux to $E_{C}$ that accounts for species or functional groups, rather than only the bulk canopy properties in the sap flux and eddy covariance footprints.

\subsection{Evaporative losses}

As expected, sap flux-scaled daily $E_{C}$ and LE followed similar trends (Fig. 5d). However, because annual $E_{C}$ comprised only $54( \pm 3) \%$ of LE, other components of total evapotranspiration required accurate quantification to make the conclusions regarding correction for nocturnal flux and scaling meaningful.

Annual estimates of $I_{C}$ are presented in Table 2. Our mean growing season estimate of $96( \pm 49) \mathrm{mm}$ was approximately $14 \%$ of growing season $P$, similar to the $14 \%$ reported in previous studies in this area (Pataki and Oren, 2003). While these mean values for the site agree well with previous results (Table 2), the standard deviation of annual $I_{C}$ (based on variation in throughfall among gauges) was nearly $60 \mathrm{~mm}$, or about $9 \%$ of $\mathrm{ET}_{\mathrm{S}}$. This variability represents the spatial heterogeneity of interception, translating to uncertainty in estimated $\mathrm{ET}_{\mathrm{S}}$.

The estimates of $E_{S}$ (Table 2) were constructed based on a subset of the wintertime eddy covariance-measured LE. These half-hourly estimates based on the wintertime relationships were close to nighttime LE values during the growing season, suggesting that the relationship was useful for $D$ values outside the range used in its derivation. We note that the estimate of $E_{S}$ is thus not entirely independent of LE with which we ultimately compare the component-sum evapotranspiration $\left(E T_{S}=E_{C}+E_{S}+I_{C}\right)$. Mean annual $E_{S}$ estimate was $103( \pm 14) \mathrm{mm}$. For a different estimate of $E_{S}$ in this stand (Stoy et al., 2006), combined modeled growing season $E_{S}$ based on radiation penetration through the canopy with wintertime measured LE, arriving at an annual value of $176 \pm 7 \mathrm{~mm}$. Our estimates of $E_{S}$ are more similar to LE measured with an eddy covariance system at $2 \mathrm{~m}$ above the forest floor in another southeastern deciduous forest $(88 \mathrm{~mm})$ where LE above the forest was similar to ours (Table 2; Wilson et al., 2001). Few other studies of broadleaf forests in this region have incorporated estimates of forest floor evaporation and this component of $\mathrm{ET}_{\mathrm{S}}$ remains the source of some uncertainty.

We assessed the agreement between estimates of various components of ET in time scales ranging from daily to interannually. Two methods for estimating forest evaporation (i.e. excluding transpiration), $L E-E_{C}$ and $E_{S}+I_{C}$, are compared in Fig. $5 d$. At the daily time scale, $E_{S}+I_{C}$ was typically higher than $L E-E_{C}$ during and immediately after rain events, but was frequently lower during periods of high radiation loads. On a monthly basis, $\mathrm{ET}_{\mathrm{S}}$ showed good agreement with LE but, 
Duke Forest, NC

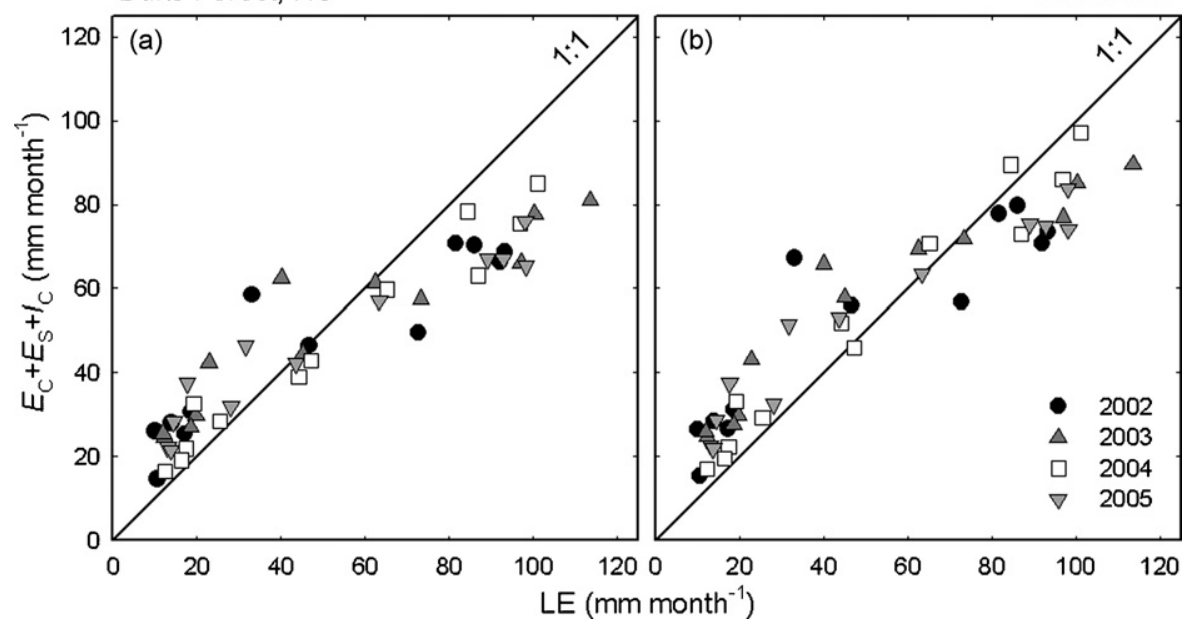

Fig. 6 - Comparison of monthly ecosystem evapotranspiration from eddy covariance-measured latent heat flux (LE) and from sap flux-scaled hydrologic budget $\left(E T_{S}\right)$. $E_{S}$ includes $E_{C}$ estimates that ignore nighttime sap flux (a) and those that account for nighttime sap flux (b).

consistent with the daily comparisons above, monthly $\mathrm{ET}_{\mathrm{S}}$ was somewhat higher during periods of low to intermediate radiation loads and lower during periods of very high radiation loads (Fig. 6). Routines used to gapfill eddy covariancemeasured LE (Falge et al., 2001; Stoy et al., 2006) may not completely account for potentially high evaporation rates from wet canopy and forest floor following rain events, because relationships derived from data obtained when surfaces are dry would underestimate evaporation following rain events when surface conductance is high. This effect is magnified during periods with low radiation loads, because sensors remain wet for longer periods producing higher proportion of unacceptable eddy covariance data. This is reflected in a significant linear increase in the number of gapfilled data points with decreasing monthly net radiation (linear regression: $p=0.0015$ ). Although underestimate of $E_{S}$ following rains will similarly bias evaporation estimates based on both methods, only LE-based evaporation estimate includes underestimated $I_{C}$ as well. The component-based $I_{C}$ estimate uses throughfall measurements that, although are spatially very variable, are largely immune to technical problems that cause a bias under particular conditions.

Periods of high radiation loads are restricted to the months in which solar zenith angle is low. During these periods, but excluding times in which the canopy is wet, $\mathrm{ET}_{\mathrm{S}}$ is often lower than LE (Bovard et al., 2005; Oren et al., 1998b; Schäfer et al., 2002; Wilson et al., 2001). This may be the result of underestimating stand-level $E_{C}$. $E_{C}$ may be underestimated for two reasons: (1) the signal may be saturating under high flux rates, as has been commonly observed (Bovard et al., 2005; Hogg et al., 1997; Wilson et al., 2001) and (2) the contribution of the sub-canopy to $E_{C}$ may be higher during periods in which radiation penetrates deeper in the canopy. The contribution of small understory individuals ( $<40 \mathrm{~mm}$ in diameter) and herbaceous vegetation was not estimated in this study, but can be large (Gholz and Clark, 2002; Vincke et al., 2005). In support of (2), Granier et al. (2000) found a linear relationship between $E_{C}$ and LE (i.e., no sign of saturation) in a study in which equal attention was given to monitoring large and small individuals. The importance of the sub-canopy to stand transpiration has been shown in many studies. Transpiration rates of canopy and sub-canopy trees compensate as stands develop, leading to a conservative forest transpiration (Phillips and Oren, 2001) as has been shown spatially among stands of different degrees of canopy closure (Roberts, 1983). Thus, we conclude that underestimation of stand-level $E_{C}$ is often the result of inadequate representation of the sub-canopy components in scaling, rather than instrument deficiencies.

Nocturnal sap flux scaled to nocturnal $E_{C}$ (occurring as recharge or water loss from leaves when PAR $=0$ ) averaged $0.19( \pm 0.11) \mathrm{mm} \mathrm{d}^{-1}$ over the growing season. The ratio of night/day $E_{C}, 0.17 \pm 0.19$, is within the range of $0-0.25$ for deciduous trees (Dawson et al., 2007). Assuming for simplicity that nocturnal $E_{C}$ is used entirely for recharge, the average nocturnal recharge rate, or even the highest rate of $\sim 0.6 \mathrm{~mm} \mathrm{~d}^{-1}$, fall well within the $\sim 1.0 \mathrm{~mm} \mathrm{~d}^{-1}$ estimated based on a relationship between recharge and sapwood area (Goldstein et al., 1998). Nocturnal LE, which includes evaporation in addition to transpiration, was less than half of nocturnal water uptake $\left(0.08 \pm 0.11 \mathrm{~mm} \mathrm{~d}^{-1}\right)$. Thus, the results suggest that at least half of this nighttime flux is used to resupply the trunk with water used earlier in the day, while some portion of the remainder may be lost as nocturnal transpiration.

At annual time scale, estimates of $\mathrm{ET}_{\mathrm{S}}$ and LE showed good agreement (see Table 2, Fig. 7). $\mathrm{ET}_{\mathrm{S}}$ was lower than LE in each year before accounting for nighttime sap flux in estimates of $E_{C}$, averaging $-6( \pm 3) \%$, reversing to $+5( \pm 3) \%$ after sap flux data were processed based on the new approach. Accounting for nocturnal flux had a more striking effect during the growing season-with the difference decreasing from -16 $( \pm 2) \%$ to $-4( \pm 3) \%$. Thus, although accounting for the effect of nocturnal fluxes did not resolve the discrepancy between $\mathrm{ET}_{\mathrm{S}}$ and LE in each day and each month - possibly due to 


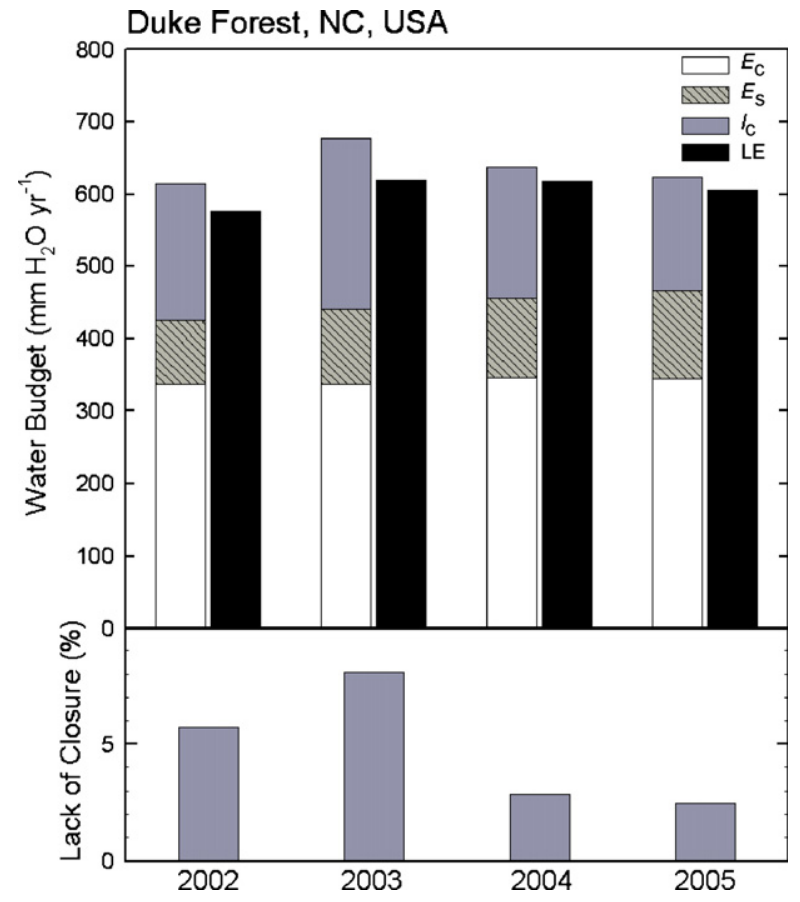

Fig. 7 - Annual ET budgets for 2002-2005 including sap flux-based $E_{\mathrm{C}}$ and the remaining evaporation components, and eddy covariance based estimates (LE). Lack of closure represents the relative difference between the two methods (using LE as the base).

underestimation of $E_{C}$ from small trees and other understory species during high radiation periods - the approach resulted in a substantial $18( \pm 2) \%$ increase in the estimate of annual $E_{C}$ $\left(61 \pm 9 \mathrm{~mm}\right.$ year $\left.^{-1}\right)$, leading to both annual and seasonal similarity of $\mathrm{ET}_{\mathrm{S}}$ and LE. The increase in estimated growing season $E_{C}$ of $22( \pm 4) \%$ based on the new method for accounting for nocturnal fluxes was intermediate compared to increases produced by other methods: a $12 \%$ increase in a Populus trichocarpa $\times$ P. deltoides plantation (Kim et al., 2008) and $30 \%$ increase in boreal Picea abies (L.) Karst. stands (Ward et al., 2008).

\subsection{Implications}

The analysis showed that mischaracterization of the footprint area is not the likely source of the reported consistent lower estimates of $\mathrm{ET}_{\mathrm{S}}$ than LE. Scaling to $\mathrm{E}_{\mathrm{C}}$ based on the hectare plot, $\mathrm{ET}_{\mathrm{S}}$ would have been only $3( \pm 3) \%$ lower than LE, while scaling based on the two sap flux plots, would have resulted in $\mathrm{ET}_{\mathrm{S}}$ that was $10( \pm 3) \%$ higher than LE. Thus, when scaled properly, and after accounting for the major contributing fluxes, seasonal and annual estimates of evapotranspiration that include sap flux-scaled $E_{\mathrm{C}}$ were in good agreement with those based on eddy covariance.

Accounting for nocturnal sap flux in trees caused by the recharge of water to upper trunks and branches, as well as nocturnal water loss, is a vital step for accurately estimating $E_{C}$. Failure to account for nocturnal fluxes is the most likely explanation for the previously observed bias towards lower estimates of component-based evapotranspiration. Nevertheless, comparisons of daily and monthly estimates of evapotranspiration indicate that the eddy covariance approach tends to underestimate during low radiation-high surface wetness periods, while the component sum tends to underestimate during periods of high radiation. Thus, the agreement between the methods at coarser temporal resolution is somewhat achieved by compensating errors, making it case specific.

\section{Acknowledgements}

This Research was supported by the Office of Science (BER) U.S. Department of Energy, Grant No. DE-FG02_00ER63015. We would like to thank H. McCarthy, H.-S. Kim, B. Poulter, K. Schäfer, E. Ward, M. Siqueira, J.-Y. Juang, K. Novick and G. Katul for assistance with data collection and analysis and D. Richter for rooting depth data.

\section{R E F E R E N C E S}

Arneth, A., Kelliher, F.M., Bauer, G., Hollinger, D.Y., Byers, J.N., Hunt, J.E., McSeveny, T.M., Ziegler, W., Vygodskaya, N.N., Milukova, I., Sogachov, A., Varlagin, A., Schulze, E.D., 1996. Environmental regulation of xylem sap flow and total conductance of Larix gmelinii trees in eastern Siberia. Tree Physiology 16 (1-2), 247-255.

Bovard, B.D., Curtis, P.S., Vogel, C.S., Su, H.-B., Schmid, H.P., 2005. Environmental controls on sap flow in a northern hardwood forest. Tree Physiology 25, 31-38.

Clearwater, M.J., Meinzer, F.C., Andrade, J.L., Goldstein, G., Holbrook, N.M., 1998. Potential errors in measurement of nonuniform sap flow using heat dissipation probes. Tree Physiology 19, 681-687.

Daley, M.J., Phillips, N.G., 2006. Interspecific variation in nighttime transpiration and stomatal conductance in a mixed New England deciduous forest. Tree Physiology 26, 411-419.

Dawson, T.E., Burgess, S.S.O., Tu, K.P., Oliveira, R.S., Santiago, L.S., Fisher, J.B., Simonin, K.A., Ambrose, A.R., 2007. Nighttime transpiration in woody plants from contrasting ecosystems. Tree Physiology 27 (4), 561-575.

Falge, E., Baldocchi, D., Olson, R., Anthoni, P., Aubinet, M., Bernhofer, C., Burba, G., Ceulemans, G., Clement, R., Dolman, H., Granier, A., Gross, P., Grunwald, T., Hollinger, D., Jensen, N.O., Katul, G., Keronen, P., Kowalski, A., Lai, C.T., Law, B.E., Meyers, T., Moncrieff, J., Moors, E., Munger, J.W., Pilegaard, K., Rannik, U., Rebmann, C., Suyker, A., Tenhunen, J., Tu, K., Verma, S., Vesala, T., Wilson, K., Wofsy, S., 2001. Gap filling strategies for long term energy flux data sets. Agricultural and Forest Meteorology 107 (1), 71-77.

Ford, C.R., Goranson, C.E., Mitchell, R.J., Will, R.E., Teskey, R.O., 2004. Dirunal and seasonal variability in the radial distribution of sap flow: predicting total stem flow in Pinus taeda trees. Tree Physiology 24, 951-960.

Ford, C.R., Hubbard, R.M., Kloeppel, B.D., Vose, J.M., 2007. A comparison of sap flux-based evapotranspiration estimates with catchment-scale water balance. Agricultural and Forest Meteorology 145 (3-4), 176-185.

Geron, C.D., Nie, D., Arnts, R.R., Sharkey, T.D., Singsaas, E.L., Vanderveer, P.J., Guenther, A., Sickles II, J.E., Kleindienst, T.E., 1997. Biogenic isoprene emission: model evaluation in 
a southeastern United States bottomland deciduous forest. Journal of Geophysical Research 102 (D15), 18889-18901.

Gholz, H.L., Clark, K.L., 2002. Energy exchange across a chronosequence of slash pine forests in Florida. Agricultural and Forest Meteorology 112 (2), 87-102.

Goldstein, G., Andrade, J.L., Meinzer, F.C., Holbrook, N.M., Cavelier, J., Jackson, P., Celis, A., 1998. Stem water storage and diurnal patterns of water use in tropical forest canopy trees. Plant Cell and Environment 21 (4), 397-406.

Granier, A., 1987. Sap flow measurements in Douglas fir tree trunks by means of a new thermal method. Annales des Sciences Forestières 44, 1-14.

Granier, A., Biron, P., Lemoine, D., 2000. Water balance, transpiration and canopy conductance in two beech stands. Agricultural and Forest Meteorology 100 (4), 291-308.

Hogg, E.H., Black, T.A., den Hartog, G., Neumann, H.H., Zimmermann, R., Hurdle, P.A., Blanken, P.D., Nesic, Z., Yang, P.C., Staebler, R.M., McDonald, K.C., Oren, R., 1997. A comparison of sap flow and eddy fluxes of water vapor from a boreal deciduous forest. Journal of Geophysical Research 102, 28929-28937.

Hsieh, C.-I., Katul, G.G., Chi, T.-W., 2000. An approximate analytical model for footprint estimation of scalar fluxes in thermally stratified atmospheric flows. Advances in Water Resources 23, 765-772.

Jarvis, P.G., McNaughton, K.G., 1986. Stomatal control of transpiration-scaling up from leaf to region. Advances in Ecological Research 15, 1-49.

Kim, H.-S., Oren, R., Hinckley, T.M., 2008. Actual and potential transpiration and carbon assimilation in an irrigated poplar plantation. Tree Physiology 28, 559-577.

Köstner, B.M.M., Schulze, E.-D., Kelliher, F.M., Hollinger, D.Y., Byers, J.N., Hunt, J.E., McSeveny, T.M., Meserth, R., Weir, P.L., 1992. Transpiration and canopy conductance in a pristine broad-leaved forest of Nothofagus: an analysis of xylem sap flow and eddy correlation measurements. Oecologia 91, 350-359.

Kozlowski, T.T., 1943. Transpiration rates of some forest tree species during the dormant season. Plant Physiology 18 (2), 252-260.

Kumagai, T., Aoki, S., Nagasawa, H., Mabuchi, T., Kubota, K., Inoue, S., Utsumi, Y., Otsuki, K., 2005. Effects of tree-to-tree and radial variations on sap flow estimates of transpiration in Japanese cedar. Agricultural and Forest Meteorology 135 (1-4), 110-116.

Lu, P., Urban, L., Zhao, P., 2004. Granier's thermal dissipation probe (TDP) method for measuring sap flow in trees: theory and practice. Acta Botanica Sinica 46, 631-646.

Meinzer, F.C., Clearwater, M.J., Goldstein, G., 2001. Water transport in trees: current perspectives, new insights and some controversies. Environmental and Experimental Botany 45, 239-262.

Oren, R., Pataki, D.E., 2001. Transpiration in response to variation in microclimate and soil moisture in southeastern deciduous forests. Oecologia 127, 549-559.

Oren, R., Ewers, B.E., Todd, P., Phillips, N., Katul, G.G., 1998a. Water balance delineates the soil layer in which moisture affects canopy conductance. Ecological Applications 8 (4), 990-1002.

Oren, R., Phillips, N., Katul, G.G., Ewers, B.E., Pataki, D.E., 1998 b. Scaling xylem sap flux and soil water balance and calculating variance: a method for partitioning water flux in forests. Annales des Sciences Forestières 55, 191-216.

Oren, R., Phillips, N., Ewers, B.E., Pataki, D.E., Megonigal, J.P., 1999. Sap-flux-scaled transpiration responses to light, vapor pressure deficit, and leaf area reduction in a flooded Taxodium distichum forest. Tree Physiology 19, 337-347.

Pataki, D.E., Oren, R., 2003. Species differences in stomatal control of water loss at the canopy scale in a mature bottomland deciduous forest. Advances in Water Resources 26, 1267-1278.

Phillips, N., Oren, R., 2001. Intra- and inter-annual variation in transpiration of a pine forest. Ecological Applications 11 (2), 385-396.

Phillips, N., Oren, R., Zimmermann, R., 1996. Radial patterns of xylem sap flow in non-, diffuse- and ring-porous tree species. Plant, Cell and Environment 19, 983-990.

Poyatos, R., Cermak, J., Llorens, P., 2007. Variation in the radial patterns of sap flux density in pubescent oak (Quercus pubescens) and its implications for tree and stand transpiration measurements. Tree Physiology 27 (4), 537-548.

Roberts, J., 1983. Forest transpiration-a conservative hydrological process. Journal of Hydrology 66 (1-4), 133-141.

Schäfer, K.V.R., Oren, R., Lai, C.-T., Katul, G.G., 2002. Hydrologic balance in an intact temperate forest ecosystem under ambient and elevated atmospheric $\mathrm{CO}_{2}$ concentration. Global Change Biology 8, 895-911.

Stoy, P.C., Katul, G.G., Siqueira, M.B.S., Juang, J.-Y., Novick, K.A., McCarthy, H.R., Oishi, A.C., Uebelherr, J.M., Kim, H.-S., Oren, R., 2006. Separating the effects of climate and vegetation on evapotranspiration along a successional chronosequence in the southeastern US. Global Change Biology 12.

Vincke, C., Granier, A., Breda, N., Devillez, F., 2005. Evapotranspiration of a declining Quercus robur (L.) stand from 1999 to 2001. II. Daily actual evapotranspiration and soil water reserve. Annals of Forest Science 62, 615-623.

Ward, E.J., Oren, R., Sigurdsson, B.D., Jarvis, P.G., Linder, S., 2008. Fertilization effects on mean stomatal conductance are mediated through changes in the hydraulic attributes of mature Norway spruce trees. Tree Physiology 28, 579-596.

Weaver, J.E., Mogensen, A., 1919. Relative transpiration of coniferous and broad-leaved trees in autumn and winter. The Botanical Gazette 68 (6), 393-424.

Williams, D.G., Cable, W., Hultine, K., Hoedjes, J.C.B., Yepez, E.A., Simonneaux, V., Er-Raki, S., Boulet, G., de Bruin, H.A.R., Chehbouni, A., Hartogensis, O.K., Timouk, F., 2004. Evapotranspiration components determined by stable isotope, sap flow and eddy covariance techniques. Agricultural and Forest Meteorology 125 (3-4), 241-258.

Wilson, K.B., Hanson, P.J., Baldocchi, D.D., 2000. Factors controlling evaporation and energy partitioning beneath a deciduous forest over an annual cycle. Agricultural and Forest Meteorology 102, 83-103.

Wilson, K.B., Hanson, P.J., Mulholland, P.J., Baldocchi, D.D., Wullschleger, S.D., 2001. A comparison of methods for determining forest evapotranspiration and its components: sap-flow, soil water budget, eddy covariance and catchment water balance. Agricultural and Forest Meteorology 106, 153-168.

Wullschleger, S.D., Hanson, P.J., 2006. Sensitivity of canopy transpiration to altered precipitation in an upland oak forest: evidence from a long-term field manipulation study. Global Change Biology 12, 97-109.

Wullschleger, S.D., Norby, R.J., 2001. Sap velocity and canopy transpiration in a sweetgum stand exposed to free-air $\mathrm{CO}_{2}$ enrichment (FACE). New Phytologist 150, 489-498.

Wullschleger, S.D., Hanson, P.J., Todd, D.E., 2001. Transpiration from a multi-species deciduous forest as estimated by xylem sap flow techniques. Forest Ecology and Management 143 (205-213). 